\title{
Anatomical optical, biomechanical and morphometric parameters of the eye in children with acquired myopia and syndrome of undifferentiated connective tissue dysplasia
}

\author{
T. Ye. Tsybulska, N. G. Zavgorodnia, O. M. Ivakhnenko, 0. Ye. Pashkova
}

Zaporizhzhia State Medical University, Ukraine

Key words: myopia, children, connective tissue diseases.

\section{Zaporozhye} medical journa 2018; 20 (3), 392-396

DOl:

10.14739/2310-1210

2018.3.130514

E-mail: tamila.eye@gmail.com

Aim of the research - to make a comprehensive assessment of anatomical, optical, biomechanical and morphometric parameters of the eye in children with acquired myopia and syndrome of undifferentiated connective tissue dysplasia.

Materials and methods. We examined patients of 2 groups: the I group - 44 children (88 eyes) with myopia of mild degree and phenotypic manifestations of connective tissue dysplasia, the II group - 40 patients (80 eyes) with myopia and without signs of connective tissue dysplasia. We measured the following parameters: corneal refractive power, corneal diameter and radius, thickness of the cornea, anterior chamber depth, lens thickness, sagittal length of the vitreous body, axial length of the eye, corneal hysteresis, peripapillary retinal nerve fiber layer thickness.

Results. We revealed significant differences in the anatomical, optical and biomechanical parameters of the visual analyzer in children with myopia of mild degree on the background of the UCTD, in contrast to children with myopia and without connective tissue dysplasia, which consisted in corneal refractive power reduction to an average of 41.25 [40.62; 41.75] D, increase in the corneal radius to an average of $8.13[7.97 ; 8.28] \mathrm{mm}$, the corneal diameter to an average of $12.5[12.1 ; 12.7] \mathrm{mm}$, the anterior chamber depth to an average of $3.8[3.4 ; 4.0] \mathrm{mm}$, the sagittal length of the vitreous body to an average of $17.6[17.3 ; 18.0] \mathrm{mm}$, the axial length of eye to an average of $24.9[24.4 ; 25.4] \mathrm{mm}$, decrease in corneal hysteresis to an average of $11.2[10.6$; $11.7] \mathrm{mm} \mathrm{Hg}$. Peripapillary retinal nerve fiber layer thickness was reduced to an average of $87[85 ; 93] \mu \mathrm{m}$.

Conclusions. The obtained data can be useful in a comprehensive assessment of ophthalmic manifestations of undifferentiated connective tissue dysplasia syndrome, in myopic process development prediction and in individual treatment tactics determination.

Кнючові слова: міопія, діти, захворювання сполучної тканини

Запорізький медичний журнал. - 2018. -

T. 20, № 3(108), C. 392-396
Анатомо-оптичні, біомеханічні та морфометричні параметри ока в дітей із набутою міопією та синдромом недиференційованої дисплазії сполучної тканини

\section{Т. Є. Цибульська, Н. Г. Завгородня, О. М. Івахненко, О. Є. Пашкова}

Мета роботи - виконати комплексне оцінювання анатомо-оптичних, біомеханічних і морфометричних показників ока в дітей із набутою міопією та синдромом недиференційованої дисплазії сполучної тканини.

Матеріали та методи. Обстежили пацієнтів двох груп: I - 44 дитини (88 очей) з міопією слабкого ступеня та фенотиповими проявами сполучнотканинної дисплазії, II група - 40 пацієнтів (80 очей) із міопією та без ознак сполучнотканинної дисплазії. Вимірювали показник заломлюваної сили рогівки, діаметр рогівки, радіус кривизни рогівки, товщину рогівки, глибину передньої камери, товщину кришталика, сагітальну довжину склоподібного тіла, аксіальну довжину очного яблука, кореальний гістерезис, перипапілярну товщину шару нервових волокон.

Результати. Виявили вірогідні відмінності за анатомо-оптичними, біомеханічними й морфометричними показниками зорового аналізатора дітей із міопією слабкого ступеня на тлі СНДСТ і дітей із міопією без сполучнотканинної дисплазії, що полягають у зниженні заломлюваної сили рогівки в середньому до $41,25[40,62 ; 41,75]$ дптр, збільшенні радіуса рогівки в середньому до $8,13[7,97 ; 8,28]$ мм, діаметра рогівки в середньому до $12,5[12,1 ; 12,7]$ мм, збільшенні глибини передньої камери в середньому до 3,8 [3,4; 4,0] мм, збільшення сагітальної довжини склоподібного тіла в середньому до 17,6 [17,3; 18,0] мм, збільшенні аксіальної довжини ока в середньому до 24,9 [24,4; 25,4] мм, зниженні корнеального гістерезису в середньому до 11,2 [10,6; 11,7] мм рт. ст., зниженні товщини шару перипапілярних нервових волокон у середньому до 87 [85; 93$] \mu \mathrm{m}$.

Висновки. Результати можуть бути корисними в комплексному оцінюванні офтальмологічних проявів синдрому недиференційованої дисплазії сполучної тканини, прогнозуванні розвитку міопічного процесу і визначенні індивідуальної тактики лікування.
Ключевые слова: миопия, Аети, заболевания соединительной ткани.

C. 392-396
Анатомо-оптические, биомеханические и морфометрические параметры глаза у детей с приобретенной миопией и синдромом недифференцированной дисплазии соединительной ткани

\section{Т. Е. Цыбульская, Н. Г. Завгородняя, Е. М. Ивахненко, Е. Е. Пашкова}

Цель работы - провести комплексную оценку анатомо-оптических, биомеханических и морфометрических показателей глаза у детей с приобретенной миопией и синдромом недифференцированной дисплазии соединительной ткани.

Материалы и методы. Обследовали пациентов 2 групп: I группа - 44 ребенка (88 глаз) с миопией слабой степени и фенотипическими проявлениями соединительнотканной дисплазии, II группа - 40 пациентов (80 глаз) с миопией и без признаков соединительнотканной дисплазии. Измеряли показатель преломляющей силы роговицы, диаметр роговицы, радиус кри- 
визны роговицы, толщину роговицы, глубину передней камеры, толщину хрусталика, сагиттальную длину стекловидного тела, аксиальную длину глазного яблока, корнеальный гистерезис, перипапиллярную толщину слоя нервных волокон.

Результаты. Установлены достоверные различия в анатомо-оптических, биомеханических и морфометрических показателях зрительного анализатора у детей с миопией слабой степени на фоне СНДСТ и детей с миопией без соединительнотканной дисплазии, которые заключаются в снижении преломляющей силы роговицы в среднем до 41,25 [40,62; 41,75] дптр, увеличении радиуса роговицы в среднем до 8,13 [7,97; 8,28] мм, диаметра роговицы в среднем до 12,5 [12,1; 12,7] мм, увеличении глубины передней камеры в среднем до 3,8 [3,4; 4,0] мм, увеличении сагиттальной длины стекловидного тела в среднем до 17,6 [17,3; 18,0] мм, увеличении аксиальной длины глаза в среднем до 24,9 [24,4; 25,4] мм, снижении корнеального гистерезиса в среднем до 11,2 [10,6; 11,7] мм рт. ст., снижении толщины слоя перипапиллярных нервных волокон в среднем до 87 [85; 93] $\mu \mathrm{m}$.

Выводы. Результаты могут быть полезными в комплексной оценке офтальмологических проявлений синдрома недифференцированной дисплазии соединительной ткани, прогнозировании развития миопического процесса и определении индивидуальной тактики лечения.

Acquired myopia is one of the main issues in ophthalmology, because even today, despite the achieved successes, it occupies a leading place in the structure of ocular pathology among the child population [5]. A distinctive feature of this pathology is its progressive course with various kinds of complications development which lead to poor vision and child's social adaptation disruption. Among the factors that increase the risk of myopia onset and progression are connective tissue structural and functional disorders of child's organism related to the undifferentiated connective tissue dysplasia syndrome, which is often accompanied by changes in connective tissue of the eye membranes [2,4,6]. According to various authors, as well as our own studies, myopia in children with connective tissue dysplasia is observed from $36.2 \%$ to $79.2 \%$ of cases, and the number of children with progressive course exceeds $37.2 \%[1,6,7]$. Therefore, it seems advisable to perform a comprehensive assessment of anatomical, optical and biomechanical parameters of the eye in children with acquired myopia and the undifferentiated connective tissue dysplasia (UCTD) syndrome. This will allow further application of the obtained results in practical work to predict the myopia course and the choice of treatment tactics.

\section{Aim of the research}

To make a comprehensive assessment of anatomical, optical, biomechanical and morphometric parameters of the eye in children with acquired myopia and syndrome of undifferentiated connective tissue dysplasia.

\section{Materials and methods}

We examined 84 children (168 eyes) with acquired myopia of mild degree (E. S. Avetisov's classification, 1968). Phenotypic signs of connective tissue dysplasia were revealed in 44 patients (88 eyes) (according to the diagnostic criteria of T. Milkovska-Dimitrova and A. Karakashov) [2]. These patients made up the I observation group. Among them, a mild degree of UCTD was revealed in 24 patients (56.8\%), moderate degree in 20 patients $(43.2 \%)$. The II group consisted of 40 patients ( 80 eyes) with myopia and without phenotypic manifestations of the UCTD. The average age of patients in the groups did not differ significantly: $9.7 \pm 0.18$ and $10.1 \pm 0.21(P>0.05)$, respectively. The average values of myopic refraction were: $-1.75 \pm 0.8 \mathrm{dpt}$ in patients of the I group and $-1.65 \pm 0.7 \mathrm{dpt}$ in patients of the II group $(P>0.05)$. Visual acuity without correction was $0.2 \pm 0.15$ in the I group and $0.2 \pm 0.11$ in the II group $(P>0.05)$. Visual acuity with correction in all patients was 1.0. Ophthalmic examination included visometry, autorefractokeratometry (MRK 3100P, Huvitz) before and after cycloplegia, biomicroscopy, ophthalmoscopy, pachymetry (VISANT OCT), optical biometry (IOL-Master, Zeiss), ultrasound (Ultrascan, Alcon), examination using analyzer of biomechanical properties of the cornea (ORA, Reichert, USA) and the optical coherent tomograph Stratus OCT 3000. We measured indicators of corneal refractive power, corneal radius and diameter, thickness of the cornea, anterior chamber depth, lens thickness, sagittal length of the vitreous body, axial eye length, corneal hysteresis, peripapillary retinal nerve fiber layer thickness. Statistical processing of the obtained results we carried out on a personal computer by the program Statistica 6.0 (StatSoft Inc., License No. AXXR712D833214FAN5). Descriptive statistics were presented in the form of median and interquartile range-Me [Q25; Q75]. A comparison of the data obtained for the two study groups we carried out using the nonparametric Mann-Whitney U-criterion. The result was considered to be statistically significant at $P$ value $<0.05$.

\section{Results and discussion}

During the research we revealed the following data of visual analyzer biometric parameters. The index of corneal refractive power in the group I patients was significantly lower than in the group II (Fig. 1): Me in the group I 41.25 [40.62; 41.75] dpt, in the group II Me 43.25 [42.75; 43.75] dpt $(\mathrm{P}<0.05)$.

From the graph in Fig. 2, which reflects the Me value and the corneal radius distribution, a significantly larger value of the corneal radius in children of the I group is seen: $8,13[7.97 ; 8.28] \mathrm{mm}$, while in children of the II group this indicator is: Me $7.7[7.5 ; 7.8] \mathrm{mm}(P<0.05)$.

From the graph in Fig. 3 significantly larger Me diameter of the corneal diameter is seen: $12.5[12.1 ; 12.7]$ $\mathrm{mm}$ in the group I and $11.5[11.3 ; 11.6] \mathrm{mm}$ in the group II $(P<0.05)$.

Investigation of the corneal thickness (Fig. 4) did not reveal reliable data between the two groups indicators. Me in the I observation group was $542[537 ; 548]$ microns, in the II group Me $540[534 ; 554]$ micron ( $P>0.05)$.

In children of the group I the anterior chamber depth was $3.8[3.4 ; 4.0] \mathrm{mm}$, while in children of the group II this indicator was significantly lower: $3.6[3.4 ; 3.7] \mathrm{mm}$ $(P<0.05)$ (Fig. 5). 


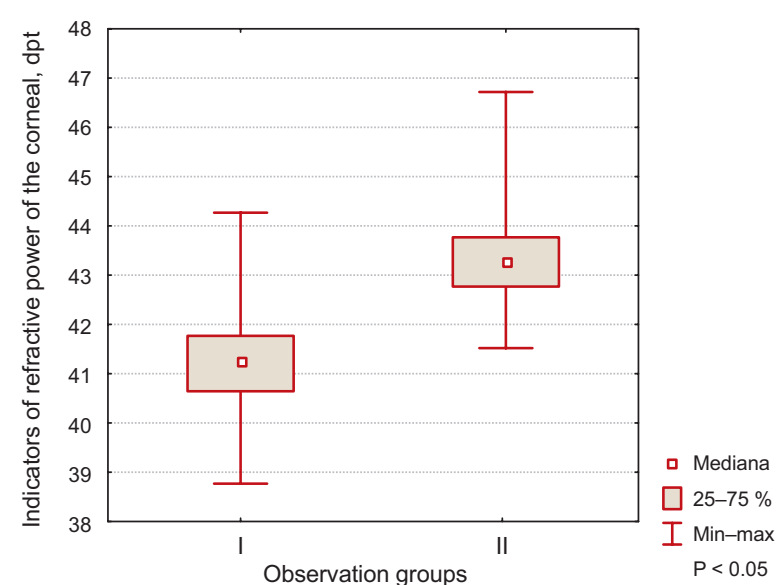

Fig. 1. Median and range of corneal refractive power indicators in patients of the I and II observation groups.

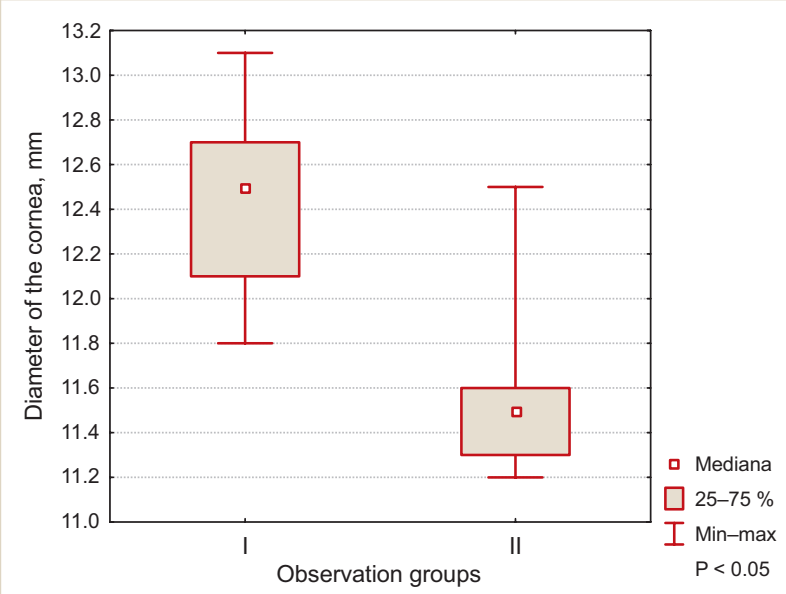

Fig. 3. Median and range of corneal diameter indicators in patients of the I and II observation groups.

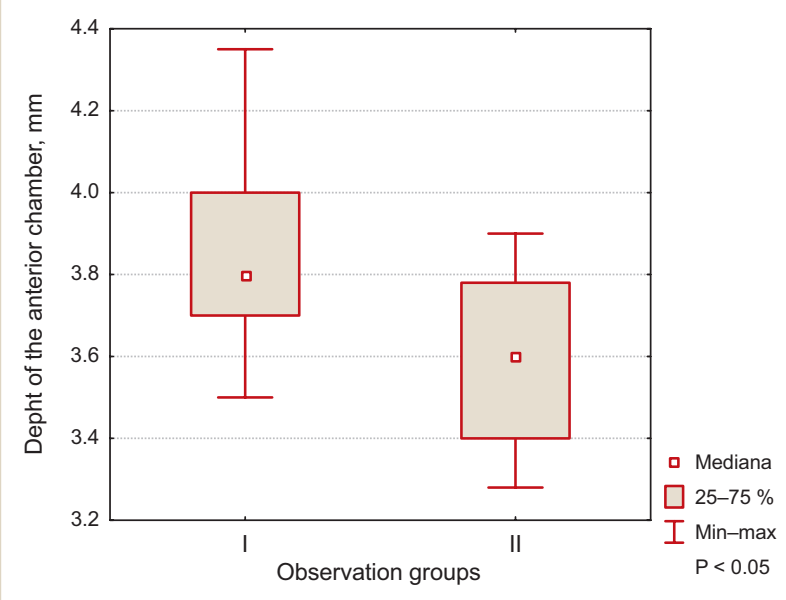

Fig. 5. Median and the range of anterior chamber depth indicators in patients of the I and II observation groups.

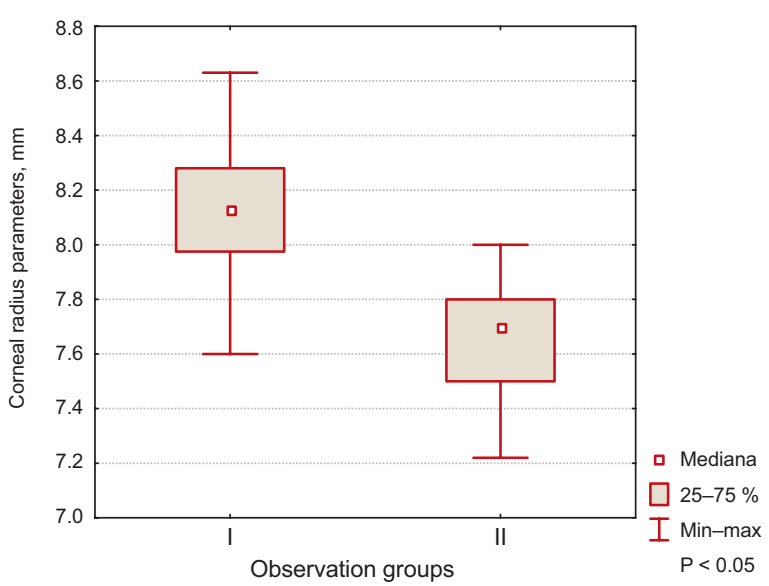

Fig. 2. Median and range of corneal radius parameters in patients of the I and II observation groups.

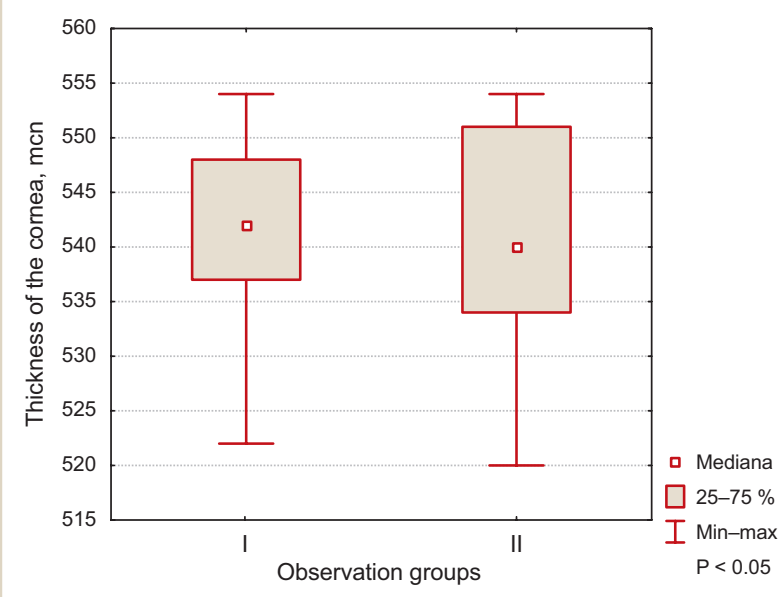

Fig. 4. Median and range of indicators of corneal thickness in patients of the I and II observation groups.

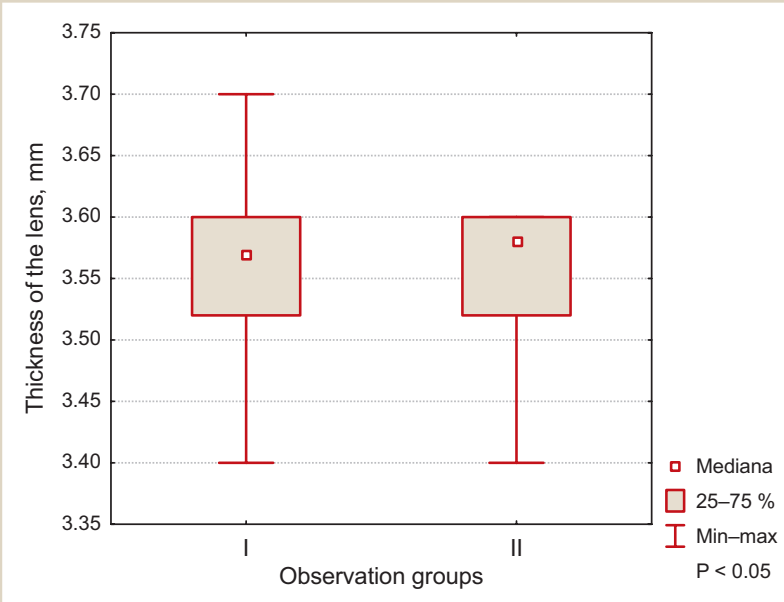

Fig. 6. Median and the range of the lens thickness in patients of the I and II observation groups.
The indicator of the lens thickness (Fig. 6) did not have a significant difference between the observation groups. In the group I it was $3.55[3.51 ; 3.63] \mathrm{mm}$, in the group II, 3.58 $[3.53 ; 3.61] \mathrm{mm}(P>0.05)$.

Me of sagittal length of the vitreous body in the I group significantly exceeded the data in patients of the II group: $17.6[17.3 ; 18.0] \mathrm{mm}$ versus Me $15.9[15.4 ; 16.1] \mathrm{mm}$ $(\mathrm{P}<0.05)$.

Comparison of the average axial eye length in patients with myopia associated with UCTD and in patients with my- 


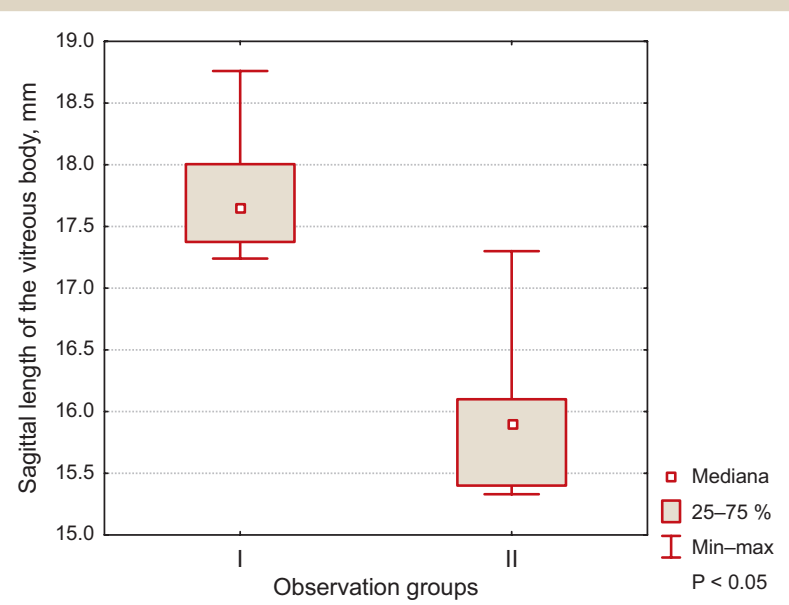

Fig. 7. Median and the range of sagittal length of the vitreous body indicators in patients of the I and II observation groups.

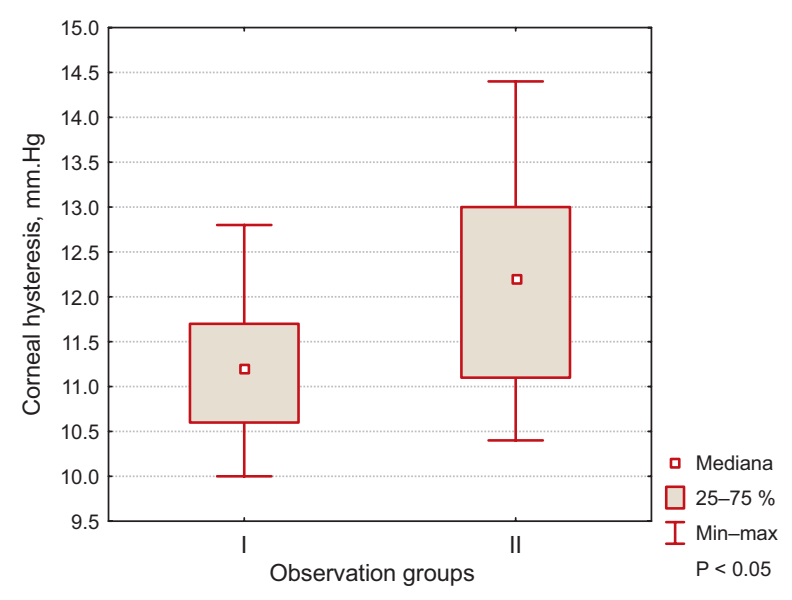

Fig. 9. Median and the range of the corneal hysteresis in patients of the I and II observation groups.

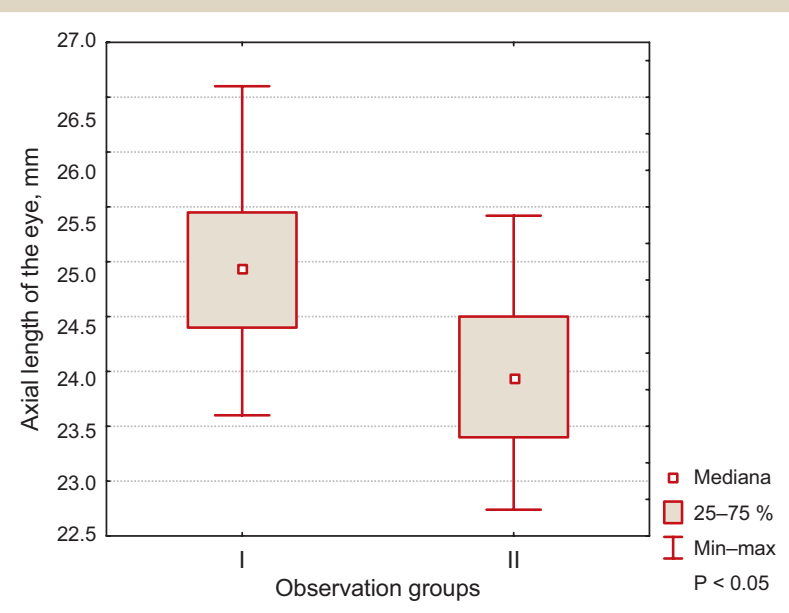

Fig. 8. Median and the range of the axial eye length in patients of the I and II observation groups.

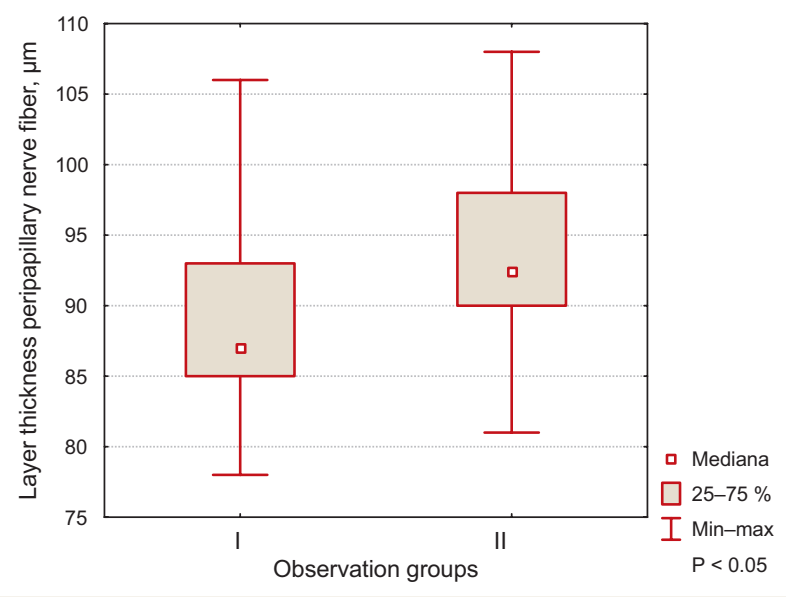

Fig. 10. Median and the range of peripapillary retinal nerve fibers layer thickness in patients of the I and II observation groups. opia without signs of UCTD revealed differences because this parameter was increased in children of the group I, although the indicators of clinical refraction did not differ significantly between groups. Thus, in children of the group I Me of the axial eye length was $24.9[24.4 ; 25.4] \mathrm{mm}$, in children of the group II Me was equal to $23.9[23.4 ; 24.5] \mathrm{mm}$ $(P<0.05)$ (Fig. 8).

A comparative analysis of the eye anatomical and optical parameters in children with myopia on the background of UCTD and with myopia without UCTD manifestations showed the following. The corneal hysteresis, which characterizes the eye cornea-scleral capsule biomechanical properties, was significantly lower in the children of the group I 11.2 [10.6; 11.7] mm Hg, in children of the II group 12,4 [11.1; 13.0] mm Hg, $(P<0.05)$, (Fig. 9).

Peripapillary retinal nerve fiber layer thickness in children of the group I was 87 [85; 93] $\mu \mathrm{m}$, which was significantly lower than in the II observation group $92.5[90 ; 98] \mu \mathrm{m}$, $\mathrm{P}<0.05$ (Fig. 10).

The analysis of the presented data allows to offer the opinion that the visual analyzer in children with myopia on the background of UCTD has certain anatomical, optical and biomechanical features, unlike children with myopia which is not associated with the UTCD. Thus, children with myopia and connective tissue dysplasia are characterized by more "flat cornea" (low refractive power of the cornea), increased corneal radius and diameter, a deeper anterior chamber, as well as larger sagittal length of the vitreous body and axial length of the eyeball with the same clinical refraction of the eye in children with connective tissue dysplasia and without it. At the same time, thickness of the cornea and lens don't have significant differences between patients with myopia on the background of UCTD and without its manifestations. Biomechanical indicators of the cornea-scleral capsule of the eye are significantly lower in children with myopia on the background of connective tissue dysplasia, as well as Peripapillary retinal nerve fiber layer thickness unlike to children with myopia without UCTD. The obtained data are consistent with the results of the authors who evaluated some parameters of the visual analyzer in individuals with undifferentiated connective tissue dysplasia clinical manifestations. So, E. M. lomdina and co-authors indicate a decrease in corneal hysteresis in children with myopia of varying degrees and joint hypermobility syndrome, which is one of the main signs of connective tissue dysplasia [3]. 
Other researchers indicate that the "flat cornea", 42.0 diopters and below, is one of the diagnostic markers for connective tissue dysplasia presence and is ametropia of any type characteristic [8]. There are also works in which data of the fundus morphological changes in people with myopia and UCTD are given, and the degree of their severity correlates with the degree of dysplasia [6].

\section{Conclusions}

1. We have revealed differences in the anatomical, optical, biomechanical and morphometric parameters of the visual analyzer in children with myopia of mild degree on the background of UCTD, in contrast to children with myopia and without connective tissue dysplasia, which consisted in corneal refractive power reduction to an average of $41.25[40.62 ; 41.75] \mathrm{D}$, increase in the corneal radius to an average of $8.13[7.97 ; 8.28] \mathrm{mm}$, the corneal diameter to an average of $12.5[12.1 ; 12.7] \mathrm{mm}$, the sagittal length of the vitreous body to an average of $3.8[3.4 ; 4.0] \mathrm{mm}$, an increase in the sagittal length of the vitreous body to an average of $17.6[17.3 ; 18.0] \mathrm{mm}$, the axial length of eye to an average of 24.9 [24.4;25.4] mm, a decrease in corneal hysteresis to an average of $11.2[10.6 ; 11.7] \mathrm{mm} \mathrm{Hg}$. Peripapillary retinal nerve fiber layer thickness was reduced to an average of $87[85 ; 93] \mu \mathrm{m}$.

2. The obtained data can be useful in a comprehensive assessment of ophthalmic manifestations of undifferentiated connective tissue dysplasia syndrome, in myopic process development prediction and in individual treatment tactics determination.

Prospects for further research. The criteria for myopic process course prediction development in children with syndrome of undifferentiated connective tissue dysplasia and treatment activities optimization in this category of children.

Фінансування: АосліАження виконане в рамках НАР Запорізького державного меАичного університету „Розробка та удосконалення шляхів корекції морфологічних та функціональних змін органа зору при катаракті, глаукомі та очних ускиадненнях цукрового Аіабету" № Аержреєстрації 0113U005087 (2013-2017).

Conflicts of Interest: authors have no conflict of interest to declare. Конфлікт інтересів: віАсутній.

Information about authors:

Tsybulska T. Ye., MD, PhD, Associate Professor of the Department of Ophthalmology, Zaporizhzhia State Medical University, Ukraine. Zavgorodnia N. G., MD, PhD, DSci, Professor, Head of the Department of Ophthalmology, Zaporizhzhia State Medical University, Ukraine.

Ivakhnenko O. M., MD, PhD, Associate Professor of the Department of Ophthalmology, Zaporizhzhia State Medical University, Ukraine.

Pashkova O. Ye., MD, PhD, DSci, Associate Professor, Department of Hospital Pediatry, Zaporizhzhia State Medical University, Ukraine.

\section{Відомості про авторів:}

Цибульська Т. Є., канА. меА. наук, доцент каф. офтальмології, Запорізький державний медичний університет, Україна.

Завгородня Н. Г., А-р меА. наук, професор, зав. каф. офтальмології, Запорізький Аержавний меАичний університет, Україна.
Івахненко О. М., канд. меА. наук, Аоцент каф. офтальмології, Запорізький Аержавний медичний університет, Україна. Пашкова О. Є., А-р меА. наук, Аоцент каф. госпітальної педіатрії, Запорізький державний медичний університет, Україна.

\section{Сведения об авторах:}

Цыбульская Т. Е., канА. меА. наук, Аоцент каф. офтальмологии, Запорожский государственный медицинский университет, Украина.

Завгородняя Н. Г., А-р меА. наук, профессор, зав. каф. офтальмологии, Запорожский государственный меАицинский университет, Украина.

Ивахненко Е. М., канд. меА. наук, доцент каф. офтальмологии, Запорожский государственный меАицинский университет, Украина.

Пашкова Е. Е., А-р меА. наук, Аоцент каф. госпитальной педиатрии, Запорожский госуАарственный медицинский университет, Украина.

Надійшла Ао редакції / Received: 10.01.2018

Після Аоопрацювання / Revised: 15.01.2018

Прийнято Ао Аруку / Accepted: 26.01.2018

\section{References}

[1] Budnik, T. V. (2014) Rezul'taty sopostavleniya fenotipicheskikh i klinicheskikh priznakov nedifferencirovannoj displazii soedinitel'noj tkani, mikroe'lementnoj obespechennosti i oftal'mologicheskikh dannykh u detej s progressiruyuschej miopiej [A comparison of phenotypic and clinical signs of connective tissue dysplasia, micronutrient sufficiency and ophthalmic data in children with progressive myopia]. Perinatologiya i peditriya, 2, 41-45. [in Russian].

[2] Iomdina, E. N., Tarutta, E. P., Markosyan, G. A., Aksenova, Yu. M., Kruzhkova, G. V., Ivashchenko, Zh. N., et al. (2013) Biomekhanicheskie pokazateli korneoskleralnoj obolochki glaza i sostoyanie soedinitel'notkannoj sistemy u detej i podrostkov s razlichnymi formami progressiruyuschej miopii [Biomechanical characteristics of the corneoscleral tunic and the state of the connective tissue system in the children and adolescents presenting with various forms of progressive myopia] Rossijskaya pediatricheskaya oftal'mologiya, 1, 18-23. [in Russian].

[3] Kadurina, T. I., \& Gorbunova, V. N. (2008) Displaziya soedinitel'no tkani [Connective tissue dysplasia]. Saint Petersburg. [in Russian].

[4] Lezhenko, G. O., Volosovec, O. P., Krivopustov, S. P., Prokhorov, E. V., Pashkova, O. E., \& Podlyanova, O. I. (2006) Syndrom nedyferentsiiovanoi dysplazii spoluchnoi tkanyny u ditei ta pidlitkiv (poshyrenist, osoblyvosti diahnostyky ta likuvannia) [The syndrome of undifferentiated connective tissue dysplasia in children and adolescents (prevalence, features of diagnosis and treatment). Zaporizhzhia: Vydavnytstvo Zaporizkoho derzhavnoho medychnoho universitetu. [in Ukrainian].

[5] Pasechnikova, N. V., Ryjkov, S. A., Naumenko, L. Yu., \& Kryzhanovskaya, T. V. (2010) Sostoyanie i aktual'nye problemy profilaktiki slepoty i slabovideniya v Ukraine [Status and current problems of prevention of blindnesss and visionin Ukraine]. Proceedings of the 12th congress of ophthalmologists of Ukraine. (P. 303-304). Odessa. [in Russian].

[6] Seleznev, A. V., \& Nasu, H. (2012) Dinamika miopicheskoj bolezni u lic $s$ sindromom displazii soedinitel'noj tkani [Dynamics of myopia in individuals with syndrome of connective tissue dysplasia]. Oftal'mokhirurgiya, 4, 73-75. [in Russian].

[7] Cibul'skaya, T. E., Zavgorodnyaya, N. G. \& Pashkova, E. E. (2017) Ocenka fenotipicheskikh markerov sindroma nedifferencirovannoj displazii soedinitel'noj tkani u detej s priobretennoj miopiej [Evaluation of phenotypic markers of the syndrome of undifferentiated connective tissue dysplasia in children with acquired myopia]. Oftal'mologicheskij zhurnal, 2, 12-17. [in Russian].

[8] Shabalov, N. P. (2012) Detskie bolezni [Childhood diseases]. Saint Petersburg. [in Russian]. 